\title{
BUILDING RELATIONSHIP BETWEEN OEM CUSTOMERS AND SUPPLIERS IN PRODUCT INNOVATION DEVELOPMENT PROCESSES IN B2B MARKET
}

\begin{abstract}
The main focus of this article is to present conditions to build relationships between Original Equipment Manufacturers (OEMs) customers and their suppliers in product innovation development processes in the $\mathrm{B} 2 \mathrm{~B}$ market. Analysis of literature and numerous observations indicate that the OEM companies developing the concept of product innovation very often also include suppliers in these processes. These processes are related to cooperation in research on new materials and technological solutions, manufacturing processes and product quality assurance. A key element to start cooperation on product innovation is to choose reliable partners. This choice is preceded by a preliminary assessment of suppliers. This is of particular important for the development of new products, which must meet stringent legal requirements regarding specific threats to the safety of users and the environmental protection. Compliance with these requirements is executed through self-assessment questionnaires, auditing and periodic scoring assessment of the suppliers. It should also be noted that the companies that are the buyers in the B2B market are not limited to impose stringent requirements to suppliers. Many OEMs driving to ensure high quality of purchased materials offer special programs to support their suppliers. Through these programs suppliers are provided with support through training and counseling. The results of these programs help ensure product safety and reduce costs jointly by the partners. This permits the transfer of new product concept in the supply chain.
\end{abstract}

Keywords: relationship marketing, supply chain management, product innovation, business-to-business

\section{INTRODUCTION}

Many Original Equipment Manufacturers (OEMs) concentrate on the selection of key suppliers, shaping long-term relations with them based on the advancement of the technical quality of product solutions. Significant conditions shaping this partnership are the speed of information exchange and individualization of approach, e.g. by means of offering a wider range of services utilising the supplier and getting involved in joint research and development of new products. The process of building relationships with suppliers can be summarized in ten phases. These are:

\footnotetext{
${ }^{1}$ Maciej Urbaniak, PhD, ScD, Professor, The University of Lodz, Faculty of Management, Chair of Logistics, 22/26 Matejki Str., 90-237 Łódź, Poland, tel.: +48 426355 215, e-mail: murb@uni.lodz.pl
} 
Setting the expectations and requirements for suppliers in terms of technical quality and service (before and after sale, frequency of orders, organizational systems (implementation of quality management standards, technical and technological capabilities as well as financial conditions;

Identification of potential suppliers;

Assessment of potential suppliers (through self-assessment questionnaires, analysis of submitted bids, auditing factories owned by providers);

Supplier classifications;

Negotiating the terms of deliveries with supplier;

Choice of supplier;

Contract agreement;

The ordering (establishing order, handling order);

Performance of the contract realization (including the transmission of orders, deliveries and monitoring purchasing process documentation);

Evaluation of co-operation and development of partnerships, including regular rating of suppliers (through the scoring or indicators), assessing the impact of cooperation with the supplier to improve the efficiency of processes in the supply chain (design, purchasing, warehousing, manufacturing, maintenance, environmental and safety management, compliance with best practices in the field of ethical conduct).

A partnership comprises a process in which the customer and the supplier gradually build strong and extensive social, economic and technical relationships. Creating partnerships usually results from some kind of evolution beginning with repeated transactions based on loyalty to the source of purchase and on confidence related to the positive image of a particular partner. Repeated transactions often transform into long-term connections in which relations are regulated by agreements. If the parties are happy with keeping to the arrangements set out in the agreements, their cooperation may transform into a close partnership ${ }^{2}$. This may generate lots of benefits for the partners and these are: improved quality of products and services, prompter of orders, preferential prices, improved communication between the supplier and the recipient (quicker and more complete exchange of information), joint research and development ${ }^{3}$. The benefits enhance the positive images of the partners. In some cases, a partnership between the supplier and the customer may transform into a strategic alliance which is based on joint achievement of specific long-term objectives.

\section{THE ROLE OF SUPPLIER IN NEW PRODUCT DEVELOPMENT}

Product innovation development processes have very often the form of projects that focus on introducing new or improving the quality of existing products ${ }^{4}$. Wheelwright and Clark have identified four types of projects related to the development of product innovations:

\footnotetext{
${ }^{2}$ S.M. Wagner, Supplier development and the relationship life-cycle, "International Journal of Production Economics" 129/2 (2011), p. 277-283.

${ }^{3}$ M. Beverland, A. Lindgreen, Relationship use and market dynamism: A model of relationship evaluation, "Journal of Marketing Management" 20/7-8 (2004), p. 825-858.

${ }^{4}$ Z. Ge, Q. Hu, Y. Xia, Firm's R\&D cooperation behavior in supply chain, "Production and operations management" 23/4 (2014), p. 599-609.
} 
Incremental improvement projects which focus on the development of technical quality of products (to improve the mechanical properties, reducing energy consumption) and/ or processes (manufacturing cost reduction by increasing efficiency);

Platform projects, aimed at creating a new model (the model of the product or part thereof) which entail a change in the manufacturing process;

Breakthrough projects whose aim is to develop new products (with new qualitative characteristics) and new processes related to their production, radically different from the previous generation of products;

Research and development projects, focused on creating knowledge on new materials and new technology that may be subject to commercialization ${ }^{5}$.

The concept of the new products often begins the so-called basic research (pure research), focusing on identifying characteristics of the product (its composition and basic functions. These research activities include defining and establishing the basic technical characteristics of the components of a product (the characteristics of components). Applied research is related to the transformation of knowledge concerning the characteristics of the product and manufacturing technology policy solutions aiming to adapt the product to meet the needs of users .In many organizations, both at the stage of basic research and applied research there is a need to find potential qualified suppliers in the field of new materials and technology (such as infrastructure). Such providers should comply with the requirements in terms of technical quality (ensure safety of the products) research and development potential, technological capacity as well as financial stability ${ }^{6}$. Successful product innovations, especially in the case of the hightech sector are very often conditioned by the quality of the cooperation between OEMs and suppliers in the processes of research and development ${ }^{7}$. For this reason, many companies switched their partners to the initial stages of product design processes ${ }^{8}$. Early suppliers' involvement in $\mathrm{R} \& \mathrm{D}$ activities can build stronger partnerships. These relations should be based on mutual trust and seeking common limiting the risks associated with new product quality assurance. This cooperation also permits partners to shorten conducted R \& D processes and reduce the costs of these activities. Early supplier Involvement also allows to jointly develop

\footnotetext{
${ }^{5}$ S.C. Wheelwright, K.B. Clark, Creating product plans to focus product development, "Harvard Business Review" 1992/70, p. 70-82.

${ }^{6}$ M. Song, C.A. Di Benedetto, Supplier's involvement and success of radical new product development in new ventures, "Journal of Operations Management" 26/1 (2008), p. 1-22; A. Ekici, An improved model for supplier selection under capacity constraint and multiple criteria, "International Journal of Production Economics" 141/2 (2013), p. 574-581.

${ }^{7}$ F. Wynstra, A. van Weele, M. Weggemann, Managing supplier involvement in product development: Three critical issues, "European Management Journal" 19/2 (2001), p. 157-167; A. Walter, Relationship-Specific Factors Influencing Supplier Involvement in Customer New Product Development, "The Journal of Supply Chain Management" 39/4 (2003); M. Hoegl, S.M. Wagner, Buyer-supplier collaboration in Product Development Project, "Journal of Management" 31/4 (2005), p. 530-548; S.M. Wagner, Tapping supplier innovation, "Journal of Supply Chain Management" 48/2 (2012), p. 37-52, 4-15; J. Ylimäki, A dynamic model of supplier-customer product development collaboration strategies, "Industrial Marketing Management" 2014/43, p. 996-1004.

${ }^{8}$ R. McIvor, P. Humphreys, T. Cadden, Supplier involvement in product development in the electronics industry: A case study, "Journal of Engineering and Technology Management" 23/4 (2006), p. 374-397; L. Melander, Buyer-Supplier Collaboration in New Product Development Between Two Equally Powerful Firms: A Case Study of ABB and SKF, "Operations and Supply Chain Management" 7/3 (2014), p. 107-113.
} 
not only the innovative potential of the partners but also their organizational capacity by improving the efficiency of processes ${ }^{9}$.

\section{THE REQUIREMENTS FOR SUPPLIERS}

The choice of a new supplier is preceded by a preliminary assessment qualification which is carried out by: filling in self-assessment questionnaires by suppliers, audits, order a trial party, collection and analysis of bids, and reference visits. Especially important source of information are the results of self-assessment and audits of suppliers that allow you to obtain information concerning:

Implemented technologies (related to the manufacturing process, operation of computerized processes);

Control the infrastructure;

Identification of processes and products,

Systems of measuring and monitoring the quality of products (materials, semi-finished products, finished products);

Innovative capability (research and development, the adaptability of new technologies, the efficiency of the implementation process innovations contribute to costs decreasing);

Implemented and integrated (quality, environmental and safety) management systems and other operational improvement tools (like Toyota Production System, Lean Management) which allow the supplier to ensure organizational efficiency ${ }^{10}$.

Increasingly, companies are developing multi-criteria evaluation systems of suppliers, in which the main criteria are: high level of technical quality (documented by product certificates), technical and organizational capacity of the supplier, price, timeliness and flexibility of supply, the provision of pre-sales services (design solutions, technical advice) and after-sales services (delivery, installation, technical service, repair and maintenance, training and counseling), financial position, ethics, forms of communication with customers ${ }^{11}$. Numerous OEM companies (that belong to the high-tech products sector) qualifying new partners for cooperation in product innovation development processes require from their suppliers the use of:

Detailed process maps (taking into account control points, process changeability, responsibility);

FMEA for products and processes (taking into account control plans, flow diagrams and defining critical parameters);

Cost analysis concerning quality and evaluations of process effectiveness;

Statistical process control (e.g. evaluation of process capability and reaching the coefficient level of $\mathrm{Cpk}>2.0$ );

\footnotetext{
${ }^{9}$ Th. E. Johnsen, Supplier involvement in new product development and innovation: Taking stock and looking to the future, "Journal of Purchasing and Supply Management", 15/3 (2009), p. 187-197.

${ }^{10}$ A Hosseininasab, A. Ahmadi, Selecting a supplier portfolio with value, development, and risk consideration, "European Journal of Operational Research" 245/1 (2015), p. 146-156; Ch.-Y. Shen, K.-T. Yu, Enhancing the efficacy of supplier selection decision-making on the initial stage of new product development: A hybrid fuzzy approach considering the strategic and operational factors simultaneously, "Expert Systems with Applications" 36/8 (2009), p. 11271-11281.

${ }^{11}$ M. Zolghadri, C. Eckert, S. Zouggar, Ph. Girard, Power-based supplier selection in product development projects, "Computers in Industry" 62/5 (2011), p. 487-500.
} 
First Part Approval;

MSA - Measurement System Analysis;

Designing experiments;

Robust design methodology;

Calculating efficiency coefficients concerning the equipment and the time of reacting in case of breakdowns;

AQAP (Advanced Product Quality Planning);

PPAP (Production Part Approval Process), and CAP (Customer Approval Package).

The high-tech sector companies may also require that the suppliers apply the specific industry standards e.g. ISO/TS 16949 in motorization sector, ISO 13485 in medical equipment industry, AS 9100 in the aircraft industry and TL 9000 in telecommunication sector. The implementation of those systems should be confirmed by appropriate certificates

\section{COOPERATION WITH SUPPLIERS IN DEVELOPING TECHNICAL DOCU- MENTATION OF PRODUCTS AND TESTING PROTOTYPES}

In the design phase the technical quality is defined by the product documentation which includes a description of the components of the product and the list of processes associated with the product realization (processing, assembly, packaging, delivery, installation at the customers), the list of elements of the infrastructure which is essential for these processes. In the case of new products, to develop this documentation, OEMs engages suppliers in the form of cooperating cross-functional teams, which are composed of representatives of various departments of the partners ${ }^{12}$. In these teams the specialist of research and development, production, maintenance, quality control, purchasing, marketing and service departments are involved. Product documentation detailed defines the composition, size (dimensions), shape and components of new product.

A jointly developed by partners description of the product is often a future specification for the supplier ${ }^{13}$. Evidence of compliance with the specifications is the First Piece Qualification (FPQ), which was confirmed by documented test results, inspection and certification of the product. On the basis of the technical documentation are designed the prototypes of new products, which are subjected to laboratory testing and production. Prototype testing of new material (alpha testing) by a supplier in cooperation with OEMs includes an assessment of the prototype as well as the manufacturing processes. The purpose of this testing is to optimize the features of the new product to confirm its compliance with the specifications and ensuring security for future users and the environment. By conducting this type of testing one could better meet the requirements of buyers, improve quality parameters to ensure appropriate service and technical advice for the client as well as resolve any significant problems with the operation of the product.

The positive results of this assessment allow prototype testing in independent laboratories (beta testing), which most often in EU countries are Notified Bodies recognized for providing certification, inspection and testing to guarantee product compliance to the defined safety

\footnotetext{
${ }^{12}$ S.M. Wagner, M. Hoegl, Involving Suppliers in Product Development: Insights from R\&D Directors and Project Managers, "Industrial Marketing Management" 35/8 (2006), p. 936-943.

${ }^{13}$ Y.-H. Lee, K.-J. Wang, Performance impact of new product development processes for distinct scenarios under different supplier-manufacturer relationships, "Mathematics and Computers in Simulation" 82/11 (2012), p. 20962108.
} 
regulations with New Approach Standardization ${ }^{14}$. Laboratory tests are mainly related to the control of the mechanical properties of products and their components under simulated extreme conditions of use. Then OEMs and suppliers carry out production tests, which are validation of the product by the manufacturer. The results of the validation can be used to refine the detailed design (change of raw materials, technological solutions) and to improve operational processes (design, manufacture, transport, installation of the product). Participation of suppliers in validation gives an opportunity to improve the quality characteristics of materials and elements of manufacturing infrastructure. ${ }^{15}$

One could also observe that many enterprises use the concept of Design for Manufacturing. They focus on the reducing the costs associated with the production and improve product quality by simplifying design and manufacturing processes (by limiting the number of parts of the product and reduction the use of materials for production $)^{16}$.

\section{LIFE CYCLE ASSESSMENT AND ECODESIGN}

More and more multinational companies require their suppliers to reduce the negative impact of products and processes on the environment through implementation of the concept of Life Cycle Assessment (LCA based on ISO series 14040 standards) and EcoDesign approach $^{17}$. This concept focuses on analyzing and reducing the negative impact of each product on the environment in all phases of their life cycle (design, manufacture, distribution, installation, use, maintenance, disposal / destruction through dematerialization), or reuse of materials (recycling). These activities aim at:

Improved material efficiency (by minimizing consumption of materials, use of materials with low impact on the environment, the use of renewable raw materials and / or use of materials recovered);

Improved energy efficiency (by reducing energy consumption, use of energy sources with low impact on the environment, the use of energy from renewable resources);

Designing (products and processes) for cleaner production and safe use of products (through the use of cleaner manufacturing techniques, avoiding the use of hazardous materials);

\footnotetext{
${ }^{14}$ R.E. Cole, From Continuous Improvement to Continuous Innovation, "Total Quality Management" 13/8 (2002), p. 1051-1056; P.A. Cauchick Miguel, Portfolio Management and New Product Development Implementation-A Case s Study in a Manufacturing Firm, "International Journal of Quality \& Reliability Management" 25/1 (2008), p. 10-23.

${ }^{15}$ Y. He, K.K. Lai, H. Sun, Y. Chen, The impact of supplier integration on customer integration and new product performance: The mediating role of manufacturing flexibility under trust theory, "International Journal of Production Economics" 2014/147, p. 260-270.

${ }^{16}$ M.A. Schilling, Strategic Management of Technological Innovation, McGraw-Hill Irwin, New York 2005, p. 229; A.K. Kulatunga, N. Karunatilake, N. Weerasinghe, R.K Ihalawatta, Sustainable Manufacturing based Decision Support model for Product Design and Development Process, 12th Global Conference on Sustainable Manufacturing, "Procedia CIRP" 2015/26, p. 87-92, J. Hartmann, R. Germain, Understanding the relationships of integration capabilities, ecological product design, and manufacturing performance, "Journal of Cleaner Production" 2015/92, p. 196-205.

${ }^{17}$ R. Karlsson, C. Luttropp, Eco -design: What's Happening?, "Journal of Cleaner Production" 2006/14, p. 1291-1442; T. Sakao, Quality Engineering for Early Stage of Environmentally Conscious Design, "The TQM Journal" 21/2 (2009), p. 182-193. F. Brones, M.M. de Carvalho, E. de Senzi Zancul, Ecodesign in project management: a missing link for the integration of sustainability in product development?, "Journal of Cleaner Production"2014/80, p. 106-118.
} 
Designing for durability (considering in this respect the length of the operation, maintainability product improvements resulting from the emergence of these technologies);

Designing for reuse of products, recovery and recycling.

Eco-design approach is based on Environmental Effect Analysis (EEA) and takes into account: identification of legal requirements, design planning, conceptual design, construction and evaluation of a prototype, production and packaging).

LCA is a complex process, involving the analysis of the profitability of investment projects with simultaneous emphasis of products on reducing their negative impact on the environment. This concept takes into account measures to determine the quantities of used materials, energy and waste generated at each process (starting from raw material extraction, through manufacturing, distribution, use and reuse / recycling until final disposal ${ }^{18}$. A particular stage in the design and development of a new product with the use of EcoDesign approach is screening. This analysis takes into account:

Laws requirements (including the restriction of use of hazardous substances, waste management) and the functionality of the product (specifications) and safety for the environment and for users);

Technological capability and business infrastructure;

Suppliers capability of providing the appropriate (new) solutions, technical quality and requirements relating to the fulfillment of requirements for improving the environmental aspects $^{19}$.

The effective application of EcoDesign and the concept of LCA helps companies meet the requirements relating environmental supplier statements (environmental product declarations) and application for the use of eco-labeling for products.

\section{SUPPLIER DEVELOPMENTS PROGRAMS}

Many international companies trying to assist local suppliers to meet their stringent requirements by offering them help in the form of consultations and training in the implementation of product innovations and improving operational processes. These activities focus on deliveries of aid in terms of:

Ensure technical quality of products,

Improve efficiency and effectiveness of processes,

Improve working conditions and improve staff qualifications,

\footnotetext{
${ }^{18}$ D. Pujari, K. Peattie, G. Wright, Organizational antecedents of environmental responsiveness in industrial new product development, "Industrial Marketing Management" 33/5 (2004), p. 381-391; K. Nakano, M. Hirao, Collaborative activity with business partners for improvement of product environmental performance using LCA, "Journal of Cleaner Production" 19/11 (2011), p. 1189-1197.

${ }^{19}$ F. Ardente, F. Mathieux, M. Recchioni, Recycling of electronic displays: Analysis of pre-processing and potential ecodesign improvements, "Conservation and Recycling" 2014/92, p. 158-171; F. Brones, M.M. de Carvalho, E. de Senzi Zancul, Ecodesign in project management: a missing link for the integration of sustainability in product development?, "Journal of Cleaner Production" 2014/80, p. 106-118; M. Fargnoli, M. De Minicis, M. Tronci, Design Management for Sustainability: An integrated approach for the development of sustainable products, "Journal of Engineering and Technology Management" 2014/34, p. 29-45; E. Benetto, C. Jury, E. Igos, J. Carton, P. Hild, Ch. Vergne, J. Di Martino, Using atmospheric plasma to design multilayer film from polylactic acid and thermoplastic starch: a screening Life Cycle Assessment, "Journal of Cleaner Production" 2015/87, p. 953-960.
} 
Reduce level of risk threats in the supply chain in order to ensure continuity of processes carried out by the partners.

Some supplier development programs aimed at improving the environmental impact of products. Green supplier development programs are based on setting goals and formulating supplier task programs, which are associated with the use of less environmentally harmful materials, implementation of more environmentally friendly technological solutions. Many industrial customers require that suppliers have implemented the requirements of European Union directives:

RoHS (Restriction of Hazardous Substances) Directive EU 2003/95/EC,

WEEE (Waste Electrical and Electronic Equipment) Directive 2001/96/EC,

EuP (Eco-design for Energy using Products) Directive 2009/125/EC,

Battery and Accumulator Directive 2006/66/EC,

Packaging Directives 94/62/EC, 2004/12/EC, COM Decision 97/129/EC,

REACH (Registration Evaluation Authorization and Restriction of Chemicals) Regulation 1907/2006/EC EC. $^{20}$.

OEMs support their suppliers providing expertise knowledge delivered through training and specialist advice. Enterprises engaging providers in joint projects related to designing new product solutions that use EcoDesign approach. Effective implementation of these programs gives a possibility to the partners improve the quality of products (lower level of noncompliance, introduce product innovations, increase reliability and security), shorten cycle processes and reduce their costs (especially in relation to operational processes such as design, customer service before and after the sale, production / services, transportation and infrastructure maintenance), as well as improve mutual communication ${ }^{21}$.

The successful implementation of these programs permits both suppliers and customers to improve the quality of products (lower the level of non-compliance, introduce product innovations, increase reliability and security), shorten cycle processes and to reduce their costs (in particular with regard to operational processes such as design, customer service before and after the sale, production/services, transportation and maintenance of infrastructure) and improve mutual communication ${ }^{22}$. Actions aimed at developing suppliers undoubtedly contribute to a reduction in transaction costs related to the exploration of new supply capacity, conducting audits and other forms of assessment, verification and qualification of the sources of pur-

\footnotetext{
${ }^{20}$ Q. Zhu, J. Sarkis, K.-H. Lai, Green supply chain management implications for "closing the loop", "The Logistics and Transportation Review" 44/1 (2008), p. 1-18; Ch-W. Hsu, A.H. Hu, Applying hazardous substance management to supplier selection using analytic network process, "Journal of Cleaner Production" 17/2 (2009), p. 255-264; Ch.-W. Hsu, T.-Ch. Kuo, Sh.-H. Chen, A.H. Hu, Using DEMATEL to develop a carbon management model of supplier selection in green supply chain management, "Journal of Cleaner Production" 56/1 (2013), p. 164-172.

${ }^{21} \mathrm{Ch}$. Bai, J. Sarkis, Evaluating green supplier development programs with a grey based rough set methodology, "Expert System with Applications" 38/11 (2011), p. 13505-13517; X. Fu, Q. Zhu, J. Sarkis, Evaluating green supplier development programs with at a telecommunications systems provider, "International Journal of Production Economics" 140/1 (2012), p. 357-367; F. Salvador, V. Villena, Supplier Integration and NPD Outcomes: Conditional Moderation Effects of Modular Design Competence, "Journal of Supply Chain Management" 49/1 (2013), p. 87-113; T. Yan, K. Dooley, Buyer-Supplier Collaboration Quality in New Product Development Projects, "Journal of Supply Chain Management"50/2 (2014), p.59-83.

${ }^{22} \mathrm{Ch}$. Bai, J. Sarkis, Evaluating green supplier development programs with a grey based rough set methodology, "Expert System with Applications" 38/11 (2011), p. 13505-13517.
} 
chase $^{23}$. In order to ensure the effectiveness of supplier development program is necessary to produce a climate of cooperation based on mutual commitment, trust and open information exchange especially in the area of performance quality (level of compliance with the requirements for the provision and improvement of products and processes ) and cost (access to financial data relating to joint ventures). Effectively implemented, the development programs of suppliers undoubtedly contribute to building the intellectual capital of the partners ${ }^{24}$.

\section{MONITORING OF SUPPLIERS DEVELOPMENT}

Many companies monitor activities of suppliers using Supplier Performance Card, collecting data, and conducting appropriate benchmarking rankings take into account their technical quality, timeliness, cost reduction, technological development, the rate of implementation by the supplier of new solutions (adaptation time changes in the process, the product), the possibility of introducing a new product, the reaction rate (for RFQ / preparation of the offer, the complaint / reported a technical problem, the implementation of corrective / preventive), flexibility (adapting to changes in customer orders, changes in the economic environment), improving environmental impact (reducing the consumption of materials / energy, reducing greenhouse gases, reducing waste generation and increase reuse of materials through the introduction of recycling), progress in the implementation of process improvement tools and products $^{25}$. Many companies also assess suppliers on the basis of their level of management focusing on their system of certificates (which conformed the implementation of organizational standards like ISO 9001, ISO 14001). They also audit suppliers periodically. Some international companies require regular reports on progress in improvement of management systems while monitoring suppliers. They also keep monitoring them regularly by means of Performance Feedback Reports Cards which contains data on lowering costs, reducing incompatibility, improving effectiveness indicators and process efficiency indicators, reducing energy consumption, shorter cycles of process completion and optimization of using production capabilities. The above-described behaviour may be presented as a cycle of constant improvement. Companies implementing management systems which conform to organisational standards much more often complete sheets and employ periodical evaluation indicators as well as audit their business partners when shaping their relations with suppliers compared to companies which do not implement systems of this type. They also require that bidders implement quality management systems and also, more and more often, an environmental management system. Observing world trends, one may notice easily that recently suppliers have been monitored from the point of view of meeting the sustainable development requirements following economic aspects (demanding high technical quality, delivery reliability, price competitiveness, technical support), more and more often also environmental aspects and social aspects (princi-

\footnotetext{
${ }^{23}$ H. Nagati, C. Rebolledo, Supplier development efforts: The suppliers' point of view, "Industrial Marketing Management" 42/1 (2013), p. 180-188.

${ }^{24}$ D.R. Krause, R.B. Handfield, B.B. Tyler, The relationships between supplier development, commitment, social capital accumulation and performance improvement, "Journal of Operations Management"25/2 (2007), p. 528-545.

${ }^{25}$ T. Yan, K.J. Dooley, Communication intensity, goal congruence, and uncertainty in buyer-supplier new product development, "Journal of Operations Management" 31/7-8 (2013), p. 523-542, S.H. Yoo, H. Shin, M.-S. Park, New product development and the effect of supplier involvement, "Omega" 2015/51, p. 107-120; Ch. Zhang, J.W. Henke Jr., S. Viswanathan, Reciprocity between buyer cost sharing and supplier technology sharing, "International Journal of Production Economics" 2015/163, p. 61-70.
} 
ples based on the concept of the Global Compact). Many OEMs define for their partners supplier the principles of code conduct. Regarding environment protection requirements, special emphasis is put on suppliers by Japanese firms which laid down detailed guidelines for suppliers. While signing contracts with suppliers, a lot of international concerns make them also sign statements according to which they will be obliged to adopt principles included in clauses of so-called Statements on Business Practices) which are connected with binding laws and ethical standards, avoiding corruption practices and fighting against attempts to bribe domestic and foreign institutions employees, avoiding employee discrimination, protection of international human rights and responsibility for the environment. It is worth noticing that these requirements are not imposed on one party only (by means of forcing suppliers to meet them). More and more companies want to shape their images as reliable partners (customers) and, therefore, draw up purchasing codes of ethics or good practice guides.

\section{CONCLUSIONS}

The international expansion of many companies, especially global companies, increases the importance of technical standardization.. One could also perceive a gap in the field of organizational solutions between international corporations and indigenous businesses. In many cases this gap is reduced by the introduction of the concept of sustainable development. International companies implementing this concept focus on the cooperating with their partners in the supply chain (suppliers and customers), offering them support through joint projects. These initiatives are aimed at improving common processes and developing concepts for new products. Cooperation between OEMs and their suppliers undoubtedly contributes to forming long-term mutually beneficial relationships between partners. Early supplier development in $\mathrm{R} \& \mathrm{D}$ processes can effectively eliminate potential errors associated with new product and mitigate the risk of not guarantees of safety for users and the environment. The effects of this cooperation allow an increase in the technological and organizational capabilities of partners, which affects their competitive advantage.

\section{REFERENCES}

[1] Ardente F., Mathieux F., Recchioni M., Recycling of electronic displays: Analysis of preprocessing and potential ecodesign improvements, "Conservation and Recycling" 2014/92, p. 158-171.

[2] Bai Ch., Sarkis J., Evaluating green supplier development programs with a grey based rough set methodology, "Expert System with Applications" 38/11 (2011), p. 13505-13517.

[3] Benetto E., Jury C., Igos E., Carton J., Hild P., Vergne Ch., Di Martino J., Using atmospheric plasma to design multilayer film from polylactic acid and thermoplastic starch: a screening Life Cycle Assessment, "Journal of Cleaner Production" 2014/87, p. 953-960.

[4] Beverland M., Lindgreen A., Relationship use and market dynamism: A model of relationship evaluation, "Journal of Marketing Management" 20/7-8 (2004), p. 825-858,

[5] Brones F., de Carvalho M.M., de Senzi Zancul E., Ecodesign in project management: a missing link for the integration of sustainability in product development?, "Journal of Cleaner Production" 2014/80, p. 106-118.

[6] Cauchick Miguel P. A., Portfolio Management and New Product Development Implementation A Case s Study in a Manufacturing Firm, "International Journal of Quality \& Reliability Management" 25/1 (2008), p. 10-23.

[7] Cole R.E., From Continuous Improvement to Continuous Innovation, "Total Quality Management" 13/8 (2002), p. 1051-1056. 
[8] Ekici A., An improved model for supplier selection under capacity constraint and multiple criteria, International Journal of Production Economics" 141/2 (2013), p. 574-581.

[9] Fargnoli M., De Minicis M., Tronci M., Design Management for Sustainability: An integrated approach for the development of sustainable products, "Journal of Engineering and Technology Management" 2014/34, p. 29-45.

[10] Fu X., Zhu Q., Sarkis J., Evaluating green supplier development programs with at a telecommunications systems provider, "International Journal of Production Economics" 140/1 (2012), p. 357-367.

[11] Ge Z., Hu Q., Xia Y., Firm's R\&D cooperation behavior in supply chain, "Production and Operations Management” 23/4 (2014), p. 599-609.

[12] Giudice F., La Rosa G., Risitano A., Product Design for Environment - a Life Cycle Approach, Taylor \& Francis, Florida, Boca Raton 2006.

[13] Hartmann J., Germain R., Understanding the relationships of integration capabilities, ecological product design, and manufacturing performance, "Journal of Cleaner Production" 2015/92, p. 196-205.

[14] He Y., Lai K.K., Sun H., Chen Y., The impact of supplier integration on customer integration and new product performance: The mediating role of manufacturing flexibility under trust theory, "International Journal of Production Economics" 2014/147, p. 260-270.

[15] Hoegl M., Wagner S.M., Buyer-supplier collaboration in Product Development Project, "Journal of Management" 31/4 (2005), p. 530-548.

[16] Hosseininasab A., Ahmadi A., Selecting a supplier portfolio with value, development, and risk consideration, "European Journal of Operational Research" 245/1 (2015), p. 146-156.

[17] Hsu Ch.-W., Hu A.H., Applying hazardous substance management to supplier selection using analytic network process, "Journal of Cleaner Production" 17/2, (2009), p. 255-264.

[18] Hsu Ch.-W., Kuo T.-Ch., Chen Sh.-H., Hu A.H., Using DEMATEL to develop a carbon management model of supplier selection in green supply chain management, "Journal of Cleaner Production" 56/1, (2013), p. 164-172.

[19] Hutt M.D., Speh Th.W., Business Marketing Management - a Strategic view of Industrial and Organizational Market, Harcourt College Publishers, 2001.

[20] Johnsen Th.E., Supplier involvement in new product development and innovation: Taking stock and looking to the future, "Journal of Purchasing and Supply Management" 15/3 (2009), p. 187-197.

[21] Karlsson R., Luttropp C., Eco-design: What's Happening?, "Journal of Cleaner Production" 2006/14, p. 1291-442.

[22] Kulatunga A.K., Karunatilake N., Weerasinghe N., Ihalawatta R.K., Sustainable Manufacturing based Decision Support model for Product Design and Development Process, 12th Global Conference on Sustainable Manufacturing, "Procedia CIRP" 2015/26, p. 87-92.

[23] Lee Y.-H., Wang K.-J., Performance impact of new product development processes for distinct scenarios under different supplier-manufacturer relationships, "Mathematics and Computers in Simulation" 82/11 (2012), p. 2096-2108.

[24] McIvor R., Humphreys P., Cadden T., Supplier involvement in product development in the electronics industry: A case study, "Journal of Engineering and Technology Management" 23/4 (2006), p. 374-397.

[25] Melander L., Buyer-Supplier Collaboration in New Product Development Between Two Equally Powerful Firms: A Case Study of ABB and SKF, "Operations and Supply Chain Management" 7/3 (2014), p. 107-113.

[26] Nakano K., Hirao M., Collaborative activity with business partners for improvement of product environmental performance using LCA, "Journal of Cleaner Production" 19/11 (2011), p. 1189-1197.

[27] Pujari D., Peattie K., Wright G., Organizational antecedents of environmental responsiveness in industrial new product development, "Industrial Marketing Management" $33 / 5$ (2004), p. 381-391. 
[28] Sakao T., Quality Engineering for Early Stage of Environmentally Conscious Design, "The TQM Journal” 21/2 (2009), p. 182-193.

[29] Salvador F., Villena V., Supplier Integration and NPD Outcomes: Conditional Moderation Effects of Modular Design Competence, "Journal of Supply Chain Management" 49/1 (2013), p. 87-113.

[30] Schilling M.A., Strategic Management of Technological Innovation, McGraw-Hill Irwin, New York 2005, p. 229.

[31] Shen Ch.-Y., Yu K.-T., Enhancing the efficacy of supplier selection decision-making on the initial stage of new product development: A hybrid fuzzy approach considering the strategic and operational factors simultaneously, "Expert Systems with Applications" 36/8 (2009), p. 11271-11281.

[32] Song M., Di Benedetto C.A., Supplier's involvement and success of radical new product development in new ventures, "Journal of Operations Management"26/1 (2008), p. 1-22.

[33] Wagner M., Hoegl M., Involving Suppliers in Product Development: Insights from $R \& D$ Directors and Project Managers, "Industrial Marketing Management" 35/8 (2006), p. 936943.

[34] Wagner S.M., Supplier development and the relationship life-cycle, "International Journal of Production Economics" 129/2 (2011), p. 277-283.

[35] Wagner S.M., Tapping supplier innovation, "Journal of Supply Chain Management" 48/2 ,(2012), p. 37-52.

[36] Walter A., Relationship-Specific Factors Influencing Supplier Involvement in Customer New Product Development, "The Journal of Supply Chain Management" 39/4 (2003), p. 4-15.

[37] Wheelwright S.C., Clark K.B., Creating Product Plans to Focus Product Development, "Harvard Business Review" 1992/70, p. 70-82.

[38] Wynstra F., van Weele A., Weggemann M., Managing supplier involvement in product development: Three critical issues, "European Management Journal" 19/2 (2001), p. 157-167.

[39] Yan T., Dooley K.J., Communication intensity, goal congruence, and uncertainty in buyersupplier new product development, "Journal of Operations Management" 31/7-8 (2013), p. 523-542.

[40] Yan T., Dooley K., Buyer-Supplier Collaboration Quality in New Product Development Projects, "Journal of Supply Chain Management" 50/2 (2014), p. 59-83.

[41] Ylimäki J., A dynamic model of supplier-customer product development collaboration strategies, "Industrial Marketing Management" 43/6 (2014), p. 996-1004.

[42] Yoo S.H., Shin H., Park M.-S., New product development and the effect of supplier involvement, "Omega" 2015/51, p. 107-120.

[43] Zhang Ch., Henke Jr. J.W., Viswanathan S., Reciprocity between buyer cost sharing and supplier technology sharing, "International Journal of Production Economics" 2015/163, p. 61-70.

[44] Zhu Q., Sarkis J., Lai K.-H., Green supply chain management implications for "closing the loop", "The Logistics and Transportation Review" 44/1 (2008), p. 1-18.

[45] Zolghadri M., Eckert C., Zouggar S., Girard Ph., Power-based supplier selection in product development projects, "Computers in Industry" $62 / 5$ (2011), p. 487-500.

\section{BUDOWANIE RELACJI POMIEDZY KLIENTAMI I DOSTAWCAMI W PROCESACH ROZWOJU INNOWACJI PRODUKTOWYCH NA RYNKU B2B}

Celem artykułu jest przedstawienie uwarunkowań budowania relacji pomiędzy klientami i dostawcami w procesach rozwoju innowacji produktowych na rynku B2B. W artykule opisano poszczególne etapy współpracy pomiędzy OEM i dostawcami w zakresie prac badawczo rozwojowych nad nowymi produktami. Analiza literatury oraz liczne obserwacje wskazują, że przedsiębiorstwa, opracowując koncepcję innowacji produktowych, włączają w te działania także do- 
stawców, prowadząc z nimi współpracę w zakresie badań nad nowymi materiałami czy rozwiązaniami technologicznymi procesów wytwarzania oraz zabezpieczania jakości wyrobu. Elementem kluczowym rozpoczęcia współpracy nad innowacjami produktowymi jest wybór odpowiednich partnerów poprzedzony odpowiednio przeprowadzoną oceną wstępną dostawców. Ma to szczególne znaczenie w wypadku prac na nowymi produktami, które mogą spełniać rygorystyczne wymagania prawne dotyczące szczególnych zagrożeń dla bezpieczeństwa użytkowników i ochrony środowiska. Spełnienie tych wymagań realizowane jest poprzez kwestionariusze samooceny dostawców, przeprowadzanie audytów oraz okresową ocenę punktową (w wypadku stałych kwalifikowanych dostawców). Przedsiębiorstwa będące nabywcami na rynku B2B nie ograniczają się wyłącznie do stawiania rygorystycznych wymagań dostawcom. Wielu producentów wyrobów gotowych, chcąc zapewnić wysoką jakość zakupywanych materiałów, oferuje swoim dostawcom specjalne programy wsparcia. Dzięki tym programom dostawcy mają zapewnione wsparcie poprzez szkolenia i doradztwo. Wyniki tych programów pozwalają zagwarantować bezpieczeństwo produktów oraz wspólnie ograniczać koszty procesów realizowanych przez partnerów.

Słowa kluczowe: marketing relacyjny, zarządzanie łańcuchem dostaw, innowacje produktowe, współpraca przedsiębiorstw

DOI: 10.7862/rz.2015.mmr.14

Tekst złożono w redakcji: maj 2015

Przyjęto do druku: maj 2015 